\title{
Photorhabdus luminescens
}

National Cancer Institute

\section{Source}

National Cancer Institute. Photorhabdus luminescens. NCI Thesaurus. Code C86649.

A species of facultatively anaerobic, Gram-negative, rod shaped bacteria assigned to the phylum Proteobacteria. This species is motile using peritrichous flagella, non-spore forming, utilizes ribose and tyrosine, bioluminescent, catalase and lecithinase positive, produces a red, pink or yellow pigment, utilizes citrate as its sole carbon and energy source, oxidase and Voges-Proskauer test negative, and does not reduce nitrate. P. luminescens is found in the intestinal lumen of entomogenous nematodes and is pathogenic to insects and humans. 